\title{
UPAYA MENINGKATKAN KEAKTIFAN BELAJAR MATEMATIKA MELALUI GAME EDUKASI QUIZIZZ DI KONDISI NEW NORMAL KELAS XII IPA SMAN 1 SUNGAI TABUK
}

\author{
DWI AGOES SUMARNI \\ SMAN 1 Sungai Tabuk \\ e-mail: dwiagoes29578@gmail.com
}

\begin{abstract}
ABSTRAK
Tujuan dari penelitian ini adalah untuk meningkatkan motivasi belajar matematika peserta didik kelas XII IPA SMAN 1 Sungai Tabuk melalui pembelajaran Media Game Edukasi Quizizz dan untuk mendeskripsikan peningkatan prestasi belajar matematika peserta didik kelas XII IPA SMAN 1 Sungai Tabuk. Penelitian ini menggunakan penelitian tindakan (action research) sebanyak tiga siklus di SMAN 1 Sungai Tabuk. Setiap siklus terdiri dari empat tahap yaitu : perencanaan, pelaksanaan, observasi, dan refleksi. Sasaran penelitian ini adalah peserta didik kelas. Data yang diperoleh berupa hasil belajar peserta didik, lembar observasi kegiatan belajar mengajar. Dari hasil analisis didapatkan bahwa keaktifan belajar matematika peserta didik di Kondisi New Normal Kelas XII IPA SMAN 1 Sungai Tabuk mengalami peningkatan dari siklus I sampai siklus III, yakni siklus I (67,7\%), siklus II (75\%), dan siklus III (87,5\%). Kesimpulan dari penelitian ini adalah metode kooperatif media game edukasi Quizizz dapat berpengaruh positif terhadap motivasi prestasi belajar peserta didik kelas XII IPA SMAN 1 Sungai Tabuk, serta model pembelajaran ini dapat digunakan sebagai salah satu alternative pembelajaran matematika.
\end{abstract}

Kata Kunci : Meningkatkan Keaktifan Belajar Matematika, Media Game Edukasi Quizizz

\section{ABSTRACT}

The purpose of this study was to increase the mathematics learning motivation of the XII IPA grade students of SMAN 1 Sungai Tabuk through the Quizizz Educational Media Game learning and to describe the increase in mathematics learning achievement of the XII IPA grade students of SMAN 1 Sungai Tabuk. This research uses action research in three cycles at SMAN 1 Sungai Tabuk. Each cycle consists of four stages, namely: planning, implementation, observation, and reflection. The target of this research is class students. The data obtained in the form of student learning outcomes, observation sheets of teaching and learning activities. From the results of the analysis, it was found that the learning activity of students in the New Normal condition of class XII IPA SMAN 1 Sungai Tabuk experienced an increase from cycle I to cycle III, namely cycle I (67.7\%), cycle II (75\%), and cycle III. (87.5\%). The conclusion of this research is that the cooperative method of educational game media Quizizz can have a positive effect on the learning achievement motivation of class XII science students at SMAN 1 Sungai Tabuk, and this learning model can be used as an alternative for learning mathematics. Keyword : Increasing Mathematics Learning Activity, Quizizz Educational Game Media

\section{PENDAHULUAN}

Saat ini kebanyakan peserta didik menyukai kemajuan teknologi interaktif dalam artian ada banyak gerakan animasi pada display (tampilan). Hal ini menjadi tantangan bagi guru untuk tetap dapat menciptakan pembelajaran yang menyenangkan, menarik dan aktif. Walaupun pembelajaran dilaksanakan jarak jauh atau daring, guru harus mampu meningkatkan keaktifan peserta didik. Tujuan penelitian ini adalah meningkatkan keaktifan belajar peserta didik di rumah pada masa pencegahan penyebaran Covid-19 melalui penerapan media game edukasi quizizz.

Game edukasi ini sebagai media pembelajaran yang diintegrasikan dengan soal- soal evaluasi diharapkan dapat membuat pembelajaran lebih menarik, menyenangkan dan aktif. Hal ini sependapat dengan Henry (2010: 53 - 54) mengemukakan tentang dampak positif 
penggunaan game yang salah satunya adalah game menyenangkan dan menghibur serta game yang memberikan latihan untuk memecahkan masalah dan logika sehingga terbiasa aktif berpikir ,belajar dan berlatih walaupun berada dirumah. Genre edukasi dipilih karena game akan digunakan untuk kepentingan pendidikan pada anak-anak dan genre quiz dipilih karena game quiz bersifat sederhana dan mudah untuk dimainkannya. Game Quizizz adalah aplikasi pendidikan berbasis game, yang membawa aktivitas multi pemain ke ruang kelas dan membuatnya di kelas latihan interaktif dan menyenangkan (Purba. 2019: 5). Implementasi menggunakan Game Quizizz, siswa dapat melakukan latihan di dalam kelas pada perangkat elektronik mereka. Tidak seperti aplikasi pendidikan lainnya, Game Quizizz memiliki karakteristik permainan seperti avatar, tema, meme, dan musik menghibur dalam proses pembelajaran. Quizizz juga memungkinkan siswa untuk saling bersaing dan memotivasi mereka belajar sehingga hasil belajar bisa meningkat. Peserta didik mengambil kuis pada saat yang sama di kelas dan melihat peringkat langsung mereka di papan peringkat. Instruktur atau guru dapat memantau prosesnya dan mengunduh hasilnya ketika kuis selesai untuk mengevaluasi kinerja siswa. Game Quizizz dapat membantu motivasi belajar siswa dan meningkatkan hasil belajar. Hal ini sejalan dengan pendapat Dewi, C. K. (2018: 43) yang mengatakan bahwa pembelajaran berbasis permainan mempunyai potensi yang baik untuk dijadikan sebagai media pembelajaran yang efektif karena dapat merangsang komponen visual dan verbal. Selaras dengan kutipan artikel Setiawan (2019) bahwa pemanfaatan media yang menarik merupakan bagian yang harus mendapat perhatian guru dalam setiap kegiatan pembelajaran agar dapat mengefektifkan pencapaian tujuan pembelajaran diantaranya pemanfaatan game edukatif

Penelitian ini berdasarkan permasalahan: (a)Bagaimanakah peningkatan prestasi belajar peserta didik dengan diterapkannya metode pembelajaran kooperatif Media Game Edukasi Quizizz? (b) Bagaimanakah pengaruh metode pembelajaran kooperatif Media Game Edukasi Quizizz terhadap motivasi belajar peserta didik kelas XII IPA SMAN 1 Sungai Tabuk tahun pelajaran 2021/2022?

Sedangkan tujuan dari penelitian ini adalah: (a) Ingin mengetahui peningkatan prestasi belajar siswa setelah diterapkannya metode pembelajaran kooperatif Media Game Edukasi Quizizz. (b) Ingin mengetahui pengaruh motivasi belajar siswa setelah diterapkan metode pembelajaran kooperatif Media Game Edukasi Quizizz.

Dengan demikian, diharapkan media game edukasi Quizizz ini dapat menjadi solusi untuk mengatasi kesulitan guru dan peserta didik selama melaksanakan PJJ di kondisi new normal serta agar pembelajaran yang dilakukan tetap berjalan efektif dalam mencapai tujuan pembelajaran yang telah dirumuskan pada RPP selama masa adaptasi kebiasaan baru (New Normal).

\section{METODE PENELITIAN}

Penelitian yang digunakan adalah penelitian tindakan kelas (PTK) yang dilaksanakan selama 2 bulan pada kelas XI IPA 1 SMAN 1 Sungai Tabuk Kabupaten Banjar Provinsi Kalimantan Selatan sebanyak 3 (tiga) siklus. Penelitian tindakan kelas ini peneliti lakukan dimulai bulan Juli sampai akhir bulan Agustus 2021. Adapun yang menjadi subyek penelitian ini adalah seluruh peserta didik di kelas XI IPA 1 sebanyak 31 orang. Dan untuk teknik pengumpulan data yang digunakan dalam penelitian ini adalah metode observasi, tes, dan dokumentasi. Metode analisis data menggunakan analisis deskriptif kualitatif. Model pembelajaran yang digunakan dalam penelitian ini adalah menggunakan media game edukasi quizizz. Prosedur penelitian tindakan kelas ini setiap siklusnya terdiri atas empat kegiatan yaitu: 1) Perencanaan, sebelum mengadakan penelitian peneliti menyusun merancang RPP dengan media edukasi Quizizz, menyiapkan instrumen lembar observasi dan tes, membuat LKPD sebagai naskah soal dalam Quizizz, mempersiapkan teman sejawat sebagai observer, dan memberi informasi awal kepada siswa melalui group whatsapp dan classroom 2) Pelaksanaan, tahapan ini penelitian menyesuaikan dengan RPP yang dirancang sesuai perencanaan baik dari 
segi langkah, waktu dan banyak pertemuan 3) Tindakan dan pengamatan atau observasi, meliputi tindakan observer dalam proses pembelajaran peserta didik dengan menggunakan lembar observasi aktivitas keaktifan peserta didik yang telah disiapkan pada tahap 1 kemudian mengunduh hasil pekerjaan peserta didik. 4) Refleksi, Tahap refleksi ini peneliti melakukan tindakan berpikir ulang terhadap apa yang sudah dicapai berdasarkan hasil pengamatan observer yaitu menganalisa, mengevaluasi dan melakukan penyimpulan data yang diperoleh, Kemudian menentukan tindakan yang harus dilakukan untuk meningkatkan keaktifan peserta didik dalam proses pembelajaran pada tahap 3 dan akan dilanjutkan pada siklus II. Pada Siklus II dan III, tahapan yang dilakukan juga sama dengan tahapan pada siklus I.

\section{HASIL DAN PEMBAHASAN}

\section{A. Deskripsi Data Hasil Penelitian \\ 1. Deskripsi data siklus I}

Pelaksanaan dimulai dengan pemberian bahan ajar sehari sebelum kegiatan pembelajaran melalui Google Classroom dan kegiatan pembelajaran melalui video menggunakan Zoom. Kegiatan pembelajaran dihadiri 31 orang siswa dan 1 observer. Pada tahap ini dilaksanakan dimulai dengan: 1) tahap perencanaan: merancang RPP yang memanfaatkan media edukasi Quizizz, mempersiapkan lembar observasi aktivitas keaktifan peserta didik, menyiapkan media, sumber, dan alat pembelajaran yang sesuai materi dengan pembelajaran daring, menyiapkan LKPD sebagai naskah soal dalam Quizizz serta kunci jawaban, menyiapkan instrument untuk pengumpulan data berupa tes dan lembar observasi, meminta rekan sejawat sebagai observer, dan menginformasikan kepada peserta didik tentang pembelajaran melalui grup whatsapp sehari sebelumnya. 2) tahapan pelaksanaan meliputi : kegiatan pendahuluan selama 10 menit, kegiatan inti 60 menit, dan kegiatan penutup selama 10 menit. 3) tahapan observasi, ditahapan ini kreteria keberhasilan penelitan adalah jika hasil observasi mencapai kriteria sangat aktif dengan rentang nilai 86 - 100, dan dengan nilai aktif dengan rentang $70-85$. Selain indikator keaktifan tersebut, juga diperhatikan nilai evaluasi seluruh siswa $\geq 65$. pelaksanaan tindakan siklus I berlangsung selama 1 kali pertemuan dengan lama waktu dalam setiap pertemuan yaitu 2x40 menit yang dilaksanakan pada hari Senin, 19 Juli 2021 dengan materi Limit Fungsi Trigonometri. Tahapan 4) tahap refleksi : kegiatan ini mengevaluasi kegiatan tahapan 1 sampai tahapan 3, dan kemudian memberikan solusi perbaikan untuk pelaksanaan siklus II.

Hasil observasi siklus I menujukkan bahwa jumlah peserta didik yang hadir pada saat proses pembelajaran berlangsung adalah 31 orang. Peserta didik yang aktif dalam kerjasama diskusi menyelesaikan Quizizz dalam grup whatsapp grup per kelompok menunjukan persentase keaktifan dibawah $70 \%$ yang berarti masih kurang aktif, begitu juga dengan kegiatan peserta menganalisis penyelesaian masalah yang diberikan dan diskusi antar kelompok secara kritis masih belum mencapai persentase keaktifan yaitu hanya berkisar 67,5 \%. Hasil evaluasi juga belum mencapai KKM yaitu hanya memperoleh rata-rata nilai 66,13 yang seharusnya batas KKM adalah nilai 70. Hal ini disebabkan karena peserta didik banyak terkendala pada sinyal sehingga keluar masuk zoom, dan peserta didik juga baru pertama kali menggunakan aplikasi zoom sehingga masih kebingungan, sedangkan saat pelaksanaan kompetisi dengan media Quizizz peserta didik kebingungan untuk masuk secara online karena harus menunggu semua peserta masuk bersamaan sehingga waktu pelaksanaan menjadi lebih lama dari waktu yang ditentukan, dan untuk pelaksanaan diskusi kelompok pada grup WA masih kurang aktif terutama presentasi terlihat canggung karena kurang percaya diri disebabkan peserta didik yang takut salah saat mengemukaan pendapatnya. Hal ini berarti ketercapaian indikator belum tercapai, sehingga penelitian dilanjutkan pada siklus II. 
Tabel 1. Hasil Observasi keaktifan peserta didik dengan media edukasi Quizizz pada siklus I

\begin{tabular}{|c|l|c|c|c|}
\hline No & Nilai & Kategori & Frekuensi & Persentase \\
\hline 1 & $86-100$ & Sangat aktif & 0 & 0 \\
\hline 2 & $70-85$ & aktif & 21 & 52,5 \\
\hline 3 & $<70$ & Kurang aktif & 6 & 15 \\
\hline \multicolumn{2}{|c|}{ Jumlah } & 27 & 67,5 \\
\hline
\end{tabular}

\section{Deskripsi data siklus II}

Pelaksanaan tetap dimulai dengan pemberian bahan ajar sehari sebelum kegiatan pembelajaran melalui Google Classroom dan kegiatan pembelajaran melalui video conference menggunakan Zoom. Pada Siklus II kegiatan pembelajaran dihadiri 31 orang peserta didik dan 1 observer. Pada tahap ini dilaksanakan dimulai dengan: 1) tahap perencanaan: pada tahapan ini dipusatkan kepada sesuatu yang belum dapat dilaksanakan dengan baik pada tindakan di siklus I. Dimulai dengan merancang RPP yang memanfaatkan media edukasi Quizizz, mempersiapkan lembar observasi aktivitas keaktifan peserta didik, menyiapkan media, sumber, dan alat pembelajaran yang sesuai materi dengan pembelajaran daring, menyiapkan LKPD yang menarik sebagai naskah soal dalam Quizizz serta kunci jawaban, menyiapkan instrument untuk pengumpulan data berupa tes dan lembar observasi, meminta rekan sejawat sebagai observer, dan menginformasikan kepada peserta didik tentang pembelajaran melalui grup whatsapp dua hari sebelumnya. 2) tahapan pelaksanaan meliputi : kegiatan pendahuluan selama 10 menit terdiri pendahuluan, apersepsi serta motivasi, dilanjutkan kegiatan inti 60 menit terdiri klarifikasi masalah, diskusi dalam kelompok, pengumpulan informasi dan data disini peserta didik mengunakan link Quizizz untuk jawaban persoalan LKPD dan LKPD dishare dalam grup WA, berbagi dan berdiskusi untuk pemecahan masalah, dilanjutkan refleksi dengan meresume dan menyimpulkan, dan kegiatan penutup selama 10 menit meliputi pengerjaan evaluasi dan penghargaan terhadap kelompok yang kinerja paling baik 3) tahapan observasi, ditahapan ini kreteria keberhasilan penelitan adalah jika hasil observasi mencapai kriteria sangat aktif dengan rentang nilai $86-100$, dan dengan nilai aktif dengan rentang 70-85. Selain indikator keaktifan tersebut, juga diperhatikan nilai evaluasi seluruh siswa $\geq 65$. pelaksanaan tindakan siklus II berlangsung selama 1 kali pertemuan dengan lama waktu dalam setiap pertemuan yaitu $2 \times 40$ menit yang dilaksanakan pada hari Senin, 26 Juli 2021 dengan materi Limit Fungsi Trigonometri. Tahapan 4) tahap refleksi : kegiatan ini mengevaluasi kegiatan tahapan 1 sampai tahapan 3, dan kemudian memberikan solusi perbaikan untuk pelaksanaan siklus III.

Hasil observasi siklus II menujukkan bahwa jumlah peserta didik yang hadir pada saat proses pembelajaran berlangsung adalah 31 orang. Peserta didik yang aktif dalam kerjasama diskusi menyelesaikan Quizizz dalam grup whatsapp grup per kelompok menunjukan persentase keaktifan meningkat, begitu juga dengan kegiatan peserta menganalisis penyelesaian masalah yang diberikan dan diskusi antar kelompok secara kritis mulai mencapai persentase keaktifan yaitu berkisar $75 \%$. Hasil evaluasi juga mencapai KKM yaitu memperoleh rata-rata nilai 80,16 sesuai batas nilai KKM adalah 70 . Hal ini disebabkan peserta didik yang terkendala pada sinyal karena jaringan pada desa tempat tinggal siswa bisa diatasi dengan mencari tempat yang lebih tinggi sehingga keluar masuk zoom bisa diminimalisir, dan peserta didik juga sudah mulai paham menggunakan aplikasi zoom. Untuk pelaksanaan kompetisi dengan media Quizizz peserta didik tampak mulai bersemangat dan mulai lancar masuk secara online walau masih harus menunggu semua peserta masuk bersamaan, dan untuk pelaksanaan diskusi kelompok pada grup WA mulai aktif dan rasa percaya diri peserta didik mulai tampak saat mengemukaan pendapatnya. Namun beberapa peserta didik masih mengalami kesulitan dalam penyelesaian masalah perhitungan pada beberapa soal karena waktu yang masih kurang tepat Hal ini berarti ketercapaian indikator tercapai namun penelitian masih dilanjutkan pada siklus III. 
Tabel 2. Hasil Observasi keaktifan peserta didik dengan media edukasi Quizizz pada siklus II

\begin{tabular}{|c|l|c|c|c|}
\hline No & Nilai & Kategori & Frekuensi & Persentase \\
\hline 1 & $86-100$ & Sangat aktif & 12 & 30 \\
\hline 2 & $70-85$ & aktif & 12 & 30 \\
\hline 3 & $<70$ & Kurang aktif & 6 & 15 \\
\hline \multicolumn{2}{|c|}{ Jumlah } & 30 & 75 \\
\hline
\end{tabular}

\section{Deskripsi data siklus III}

Untuk siklus III perencanaan perbaikan adalah merangsang kemampuan peserta didik dalam ketelitian membaca dan menyelesaikan soal, serta refleksi lebih dalam terhadap masing - masing individu peserta didik yang nilainya masih dibawah indikator ketercapaian KKM dengan memberikan motivasi lebih bagi peserta didik yang masih kurang aktif saat diskusi kelompok.

Pelaksanaan tetap dimulai dengan pemberian bahan ajar sehari sebelum kegiatan pembelajaran melalui Google Classroom dan kegiatan pembelajaran melalui video conference menggunakan Zoom. Pada Siklus III kegiatan pembelajaran dihadiri 31 orang peserta didik dan 2 observer. Pada tahap ini dilaksanakan dimulai dengan: 1) tahap perencanaan: pada tahapan ini dipusatkan kepada sesuatu yang belum dapat dilaksanakan dengan baik pada tindakan di siklus I dan II. Dimulai dengan merancang RPP yang memanfaatkan media edukasi Quizizz, mempersiapkan lembar observasi aktivitas keaktifan peserta didik, menyiapkan media, sumber, dan alat pembelajaran yang sesuai materi dengan pembelajaran daring, menyiapkan LKPD yang menarik sebagai naskah soal dalam Quizizz serta kunci jawaban, menyiapkan instrument untuk pengumpulan data berupa tes dan lembar observasi, meminta rekan sejawat sebagai observer sebanyak 2 orang, dan menginformasikan kepada peserta didik tentang pembelajaran melalui grup whatsapp dua hari sebelumnya. 2) tahapan pelaksanaan meliputi : kegiatan pendahuluan selama 10 menit terdiri pendahuluan, apersepsi serta motivasi, dilanjutkan kegiatan inti 60 menit terdiri klarifikasi masalah, diskusi dalam kelompok, pengumpulan informasi dan data disini peserta didik mengunakan link Quizizz untuk jawaban persoalan LKPD dan LKPD dishare dalam grup WA, berbagi dan berdiskusi untuk pemecahan masalah, dilanjutkan refleksi dengan meresume dan menyimpulkan, dan kegiatan penutup selama 10 menit meliputi pengerjaan evaluasi dan penghargaan terhadap kelompok yang kinerja paling baik 3) tahapan observasi, ditahapan ini kreteria keberhasilan penelitan adalah jika hasil observasi mencapai kriteria sangat aktif dengan rentang nilai 86 - 100, dan dengan nilai aktif dengan rentang $70-85$. Selain indikator keaktifan tersebut, juga diperhatikan nilai evaluasi seluruh siswa $\geq 65$. pelaksanaan tindakan siklus III berlangsung selama 1 kali pertemuan dengan lama waktu dalam setiap pertemuan yaitu 2x40 menit yang dilaksanakan pada hari Senin, 2 Agustus 2021 dengan materi Limit Fungsi Trigonometri. Tahapan 4) tahap refleksi : kegiatan ini mengevaluasi kegiatan tahapan 1 sampai tahapan 3.

Hasil observasi siklus III menujukkan bahwa jumlah peserta didik yang hadir pada saat proses pembelajaran berlangsung adalah 31 orang. Peserta didik yang aktif dalam kerjasama diskusi menyelesaikan Quizizz dalam grup whatsapp grup per kelompok menunjukan persentase keaktifan semakin meningkat, begitu juga dengan kegiatan peserta menganalisis penyelesaian masalah yang diberikan dan diskusi antar kelompok secara kritis mulai mencapai persentase keaktifan yaitu $87,5 \%$ oleh penilaian observer 1 dan $85 \%$ untuk penilaian observer 2 Hasil evaluasi juga mencapai KKM yaitu memperoleh rata-rata nilai 82,26 sesuai batas nilai KKM adalah 70. Hal ini disebabkan sebagian besar peserta didik sudah lancar jaringan di tempat tinggalnya dan peserta didik semakin mahir menggunakan aplikasi zoom dan semangat dalam berdiskusi. 
ACTION : Jurnal Inovasi Penelitian Tindakan Kelas dan Sekolah

Vol 2. No 1. Januari 2022 e-ISSN : 2798-5733 P-ISSN : 2798-5741

Tabel 3. Hasil Observasi keaktifan peserta didik dengan media edukasi Quizizz pada siklus II

\begin{tabular}{|c|c|c|c|c|c|c|}
\hline No & Nilai & Kategori & \multicolumn{2}{c|}{ Observer 1 } & \multicolumn{2}{c|}{ Observer 2 } \\
\hline & & & Frekuensi & Persentase & Frekuensi & Persentase \\
\hline 1 & $86-100$ & Sangat aktif & 20 & 50 & 16 & 40 \\
\hline 2 & $70-85$ & aktif & 15 & 37,5 & 18 & 45 \\
\hline 3 & $<70$ & Kurang aktif & 0 & 0 & 0 & 0 \\
\hline \multicolumn{2}{|c|}{ Jumlah } & 35 & 87,5 & 34 & 85 \\
\hline
\end{tabular}

\section{B. Pembahasan}

Penelitian tindakan kelas yang dilakukan ini dilakukan untuk mengetahui apakah penggunaan Media Game Edukasi Quizizz dapat Meningkatkan Keaktifan Belajar Matematika Siswa Dalam Pembelajaran Daring di Kondisi New Normal Kelas XII IPA di SMA Negeri 1 Sungai Tabuk.

Hasil 1. Observasi Peningkatan skor keaktifan Peserta Didik

\begin{tabular}{|c|c|c|c|c|c|}
\hline \multirow[t]{2}{*}{ No } & \multirow[t]{2}{*}{ Aktivitas Peserta Didik } & \multirow{2}{*}{$\begin{array}{l}\text { Siklus I } \\
\text { Observer 1 }\end{array}$} & \multirow{2}{*}{$\begin{array}{l}\text { Siklus II } \\
\text { Observer } 1\end{array}$} & \multicolumn{2}{|c|}{ Siklus III } \\
\hline & & & & $\begin{array}{c}\text { Observer } \\
1\end{array}$ & $\begin{array}{c}\text { Observer } \\
2\end{array}$ \\
\hline 1 & $\begin{array}{l}\text { Aktif dalam kerja sama diskusi } \\
\text { menyelesaikan Quizizz dalam } \\
\text { WhatsApp Grup kelompok }\end{array}$ & 2 & 2 & 3 & 3 \\
\hline 2 & $\begin{array}{l}\text { Aktif melakukan analisis } \\
\text { penyelesaian masalah }\end{array}$ & 2 & 3 & 3 & 3 \\
\hline 3 & $\begin{array}{l}\text { Mengerjakan LKPD dalam } \\
\text { Quizizz tepat waktu (kelompok) }\end{array}$ & 3 & 4 & 4 & 4 \\
\hline 4 & $\begin{array}{l}\text { Berpikir kritis dalam diskusi antar } \\
\text { kelompok }\end{array}$ & 2 & 2 & 3 & 3 \\
\hline 5 & $\begin{array}{l}\text { Aktif mengemukakan pendapat } \\
\text { dan bertanya pada presentasi } \\
\text { kelompok }\end{array}$ & 3 & 2 & 4 & 3 \\
\hline 6 & $\begin{array}{l}\text { Aktif menanggapi pertanyaan } \\
\text { yang diajukan }\end{array}$ & 3 & 3 & 4 & 4 \\
\hline 7 & $\begin{array}{l}\text { Mampu menyelesaikan masalah } \\
\text { dalam LKPD dengan tepat }\end{array}$ & 3 & 3 & 3 & 3 \\
\hline 8 & $\begin{array}{l}\text { Melaksanakan tugas yang } \\
\text { diberikan tanpa harus diingatkan. }\end{array}$ & 3 & 3 & 3 & 3 \\
\hline 9 & $\begin{array}{l}\text { Memenuhi semua tugas / tagihan } \\
\text { yang diberikan }\end{array}$ & 3 & 4 & 4 & 4 \\
\hline \multirow[t]{3}{*}{10} & $\begin{array}{l}\text { Mampu membuat kesimpulan dari } \\
\text { pembelajaran }\end{array}$ & 3 & 4 & 4 & 4 \\
\hline & Jumlah & 27 & 30 & 35 & 34 \\
\hline & Nilai & 67,5 & 75 & 87,5 & 85 \\
\hline
\end{tabular}

Adapun Kriterianya sebagai berikut:

\begin{tabular}{|c|c|}
\hline Nilai & Keterangan \\
\hline $86-100$ & Sangat aktif \\
\hline $70-85$ & aktif \\
\hline$<70$ & Kurang aktif \\
\hline
\end{tabular}

Dari data tabel diatas dapat dilihat peningkatan skor keaktifan siswa berdasarkan hasil observasi mulai dari skor Siklus I, skor siklus II, dan skor siklus III. Untuk lebih jelasnya dapat dilihat pada Grafik Skor Peningkatan aktivitas keaktifan siswa tiap siklus berikut : 


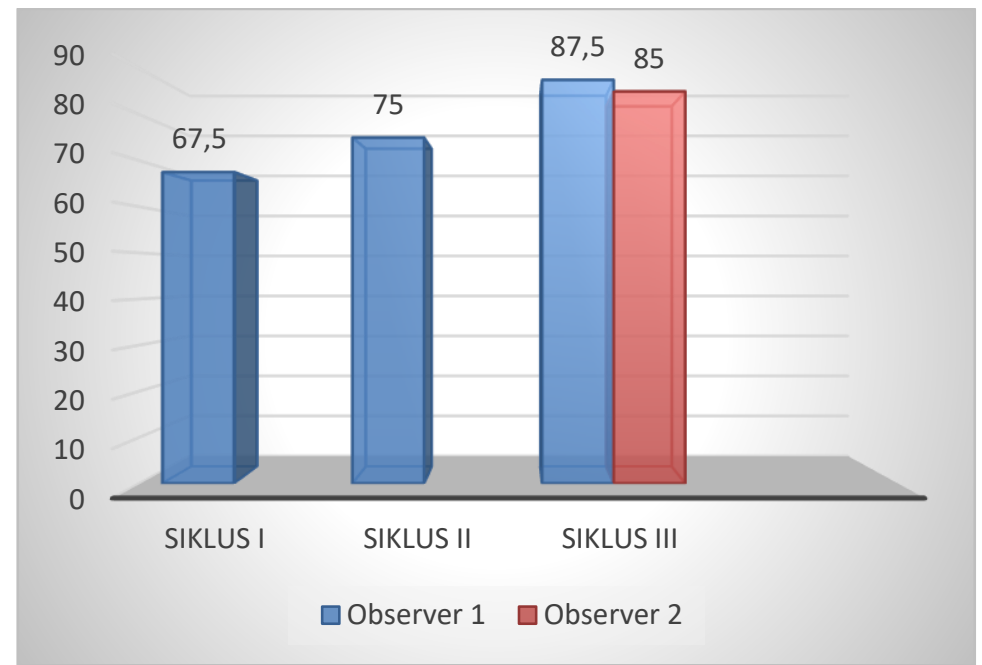

Gambar 1. Grafik skor Peningkatan Aktivitas keaktifan Peserta Didik Siklus I, II, dan III

Dari grafik di atas, terlihat adanya peningkatan aktivitas keaktifan belajar peserta didik dimana pada siklus I, aktivitas peserta didik menunjukkan 67,5\% kurang aktif, pada siklus II meningkat menjadi $75 \%$ tergolong aktif, dan pada siklus III terjadi peningkatan keaktifan oleh dua orang observer dengan penilaian persentase 87,5 dan 85 yang tergolong sangat aktif.

Sesuai pendapat dari Henry (2010) bahwa dampak positif penggunaan game salah satunya adalah game memberikan suasana menyenangkan dan menghibur untuk memecahkan masalah sehingga terbiasa aktif berpikir , belajar dan berlatih walaupun berada dirumah, Hal ini terlihat dari ketuntasan pada siklus 3 yang dipengaruhi oleh suasana menyenangkan saat pembelajaran dengan media edukasi Quizizz, sehingga peserta didik merasa tertantang untuk berkompetisi. Belajar sambal bermain.

Peningkatan keaktifan belajar peserta didik padan siklus 3 karena game edukasi Quizizz memberikan suasana yang menyenangkan pada pembelajaran matematika membuat peserta didik termotivasi untuk belajar dan bersemangat saat pembelajaran sehingga dapat meningkatkan keaktifan peserta didik bahkan berdampak pada nilai evaluasi yang memuaskan. Sebagaimana kutipan artikel Agung setiawan dkk (2019) bahwa pemanfaatan media yang menarik merupakan bagian yang harus mendapat perhatian guru dalam setiap kegiatan pembelajaran agar dapat mengefektifkan pencapaian tujuan pembelajaran diantaranya pemanfaatan game edukatif. Pelaksanaan kompetisi dengan media Quizizz peserta didik tampak semakin bersemangat dan lancar masuk secara online, dan untuk pelaksanaan diskusi kelompok pada grup WA semakin aktif dengan rasa percaya diri peserta didik mengemukaan pendapatnya dan menanggapi hasil jawaban kelompok lain. Hal ini berarti ketercapaian indikator tercapai. Sependapat dengan Dewi, C. K. (2018: 43) yang mengatakan bahwa pembelajaran berbasis permainan mempunyai potensi yang baik untuk dijadikan sebagai media pembelajaran yang efektif karena dapat merangsang komponen visual dan verbal

\section{KESIMPULAN}

Berdasarkan hasil penelitian dan pembahasan yang telah diuraikan diatas maka dapat disimpulkan bahwa penggunaan media game edukasi Quizizz dapat meningkatkan keaktifan belajar matematika siswa di Kondisi New Normal Kelas XII IPA 1 SMA Negeri 1 Sungai Tabuk. Peningkatan tampak dari awal siklus I dimana aktivitas peserta didik semula menunjukkan nilai 67,5 yang tergolong kurang aktif meningkat menjadi 75 pada siklus II yang tergolong aktif,dan pada siklus III bertambah peningkatan keaktifan dengan dua orang observer menilai 87,5 dan 85 tergolong sangat aktif.

Keunggulan dalam penggunaan media game edukasi Quizizz dalam pembelajaran matematika yaitu pembelajaran matematika menjadi lebih bermakna dan menyenangkan karena terjalin kerjasama dalam kompetisi Quizizz agar dapat menyelesaikan tugas dan 
kelompoknya menjadi pemenang. Peserta didik menjadi semangat dan lebih aktif baik dalam bertanya maupun mengemukakan pendapat atau bertukar informasi. Sehingga penggunaan media game edukasi Quizizz dapat meningkatkan keaktifan belajar matematika siswa di Kondisi New Normal Kelas XII IPA 1 SMA Negeri 1 Sungai Tabuk.

\section{DAFTAR PUSTAKA}

Agung setiawan dkk. (2019). "Implementasi Media Game Edukasi Quizizz Untuk Meningkatkan Hasil Belajar Matematika Sistem Persamaan Linear Tiga Variabel Kelas 7 SMA Negeri 15 Semarang Tahun Pelajaran 2019/2020” Seminar Nasional Edusaintek FMIPA UNIMUS.

Dewi, C.K (2018). Pengembangan Alat Evaluasi Menggunakan Aplikasi Kahoot pada pembelajaran Matematika Kelas X. Skripsi S1. Fakulltas Tarbiyah dan Keguruan Universitas Islam Negeri Raden Intan Lampung (2020) dari http://repository.radenintan.ac.id/4286/1/SKRIPSICAHYAKURNIA.pdf

Herliandry, L. D., Nurhasanah, N., Suban, M. E., \& Kuswanto, H. (2020). Pembelajaran pada masa pandemi covid-19. JTP-Jurnal Teknologi Pendidikan, 22(1), 65-70.

Henry, S. (2010). Cerdas dengan Game. Jakarta: PT Gramedia Pustaka Utama.

Mustakim, M. (2020). Efektivitas pembelajaran daring menggunakan media online selama pandemi covid-19 pada mata pelajaran matematika. Al asma: Journal of Islamic Education, 2(1), 1-12.

Purba, L. S. L. (2019). Peningkatan Konsentrasi Belajar Mahasiswa Melalui Pemanfaatan Evaluasi Pembelajaran Quizizz Pada Mata Kuliah Kimia Fisika I. JDP. 12(1) : 29

Rusmana, I. M. (2020). Pembelajaran Matematika Menyenangkan Dengan Aplikasi Kuis Online Quizizz. Prosiding Sesiomadika, 2(1a).

Suharsimi, Arikunto, dkk. (2006). Penelitian Tindakan Kelas. Jakarta: PT. Bumi Aksara 